\title{
Pulmonary exacerbation due to colistin-resistant Stenotro- phomonas maltophilia in a Bulgarian cystic fibrosis patient
}

\author{
Guergana P. Stoyanova' , Tanya V. Strateva ${ }^{2}$, Svetlana T. Atanasova ${ }^{2}$, Dimitrinka S. Miteva ${ }^{1}$, \\ Vera E. Papochieva ${ }^{1}$, Penka I. Perenovska' \\ ${ }^{1}$ Pediatric Clinic, Alexandrovska University Hospital, Medical University of Sofia, Sofia, Bulgaria \\ ${ }^{2}$ Department of Medical Microbiology, Faculty of Medicine, Medical University of Sofia, Bulgaria
}

\section{Correspondence: Gergana P. Stoyanova, Pediatric clinic , Alexandrovska University Hospital, Medical University of Sofia, Sofia, Bulgaria, $1 \mathrm{G}$. Sofijski Blvd Sofia, 1431, Bulgaria E-mail:gal_ps@yahoo.co.uk Tel.: +359889751165}

Received: 18 August 2015

Accepted: 18 May 2016

Published: 30 June 2016

Key words: cystic fibrosis, multidrug resistance, Stenotrophomonas maltophilia

Citation: Stoyanova GP, Strateva TV, Atanasova ST, Miteva DS, Papochieva VE, Perenovska PI. Pulmonary exacerbation due to colistin-resistant Stenotrophomonas maltophilia in a Bulgarian cystic fibrosis patient.

Folia Medica 2016;58(2);136-140, doi: 10.1515/folmed-2016-0014

\begin{abstract}
In patients with cystic fibrosis (CF) lung damage secondary to chronic infection is the main cause of death. Treatment of lung disease to reduce the impact of infection, inflammation and subsequent lung injury is therefore of major importance. As Pseudomonas aeruginosa is the dominant pathogen in CF patients it has been the major target of all treatment strategies, possible antibiotic regimens and recommendations for years. More sophisticated antibiotic therapies introduced over the last decades have helped to improve the prognosis in cystic fibrosis, but then new multidrug-resistant pathogens emerged.

We present a case of cystic fibrosis in a 16-year-old boy with pulmonary exacerbation due to colistin-resistant Stenotrophomonas maltophilia. This case raises some interesting questions regarding the antibiotic policy and treatment options in our country for patients with CF and multidrug-resistant strains. Colistin is used at present in Bulgaria as a strategic last option for the CF patients but with the advent of new more drug-resistant strains therapeutic approach should change for instance, there should be restrictions imposed on the use of levofloxacin and trimethoprim/sulfamethoxazole which are regarded as "cheap and not so potent" antibiotics suitable for any infection and use them only in strict dependence on the respective culture results.
\end{abstract}

\section{INTRODUCTION}

Cystic fibrosis is the most common lethal autosomal recessive hereditary disorder in Caucasians. ${ }^{1}$ The prognosis of the disease is substantially dependent on the chronic respiratory infection and inflammation, a hallmark of $\mathrm{CF}^{2}$ Antibiotic therapy aims at eradicating Pseudomonas aeruginosa, the major bacterial pathogen in $\mathrm{CF}$, after early lung infection, and improved regimens to treat chronic $P$. aeruginosa infection have played a major role in increasing median survival of $\mathrm{CF}$ patients to 40 years during the last decades. ${ }^{3}$ However, during the last 5 years, reported survival rates appear to have reached a plateau ${ }^{4}$ and one of the reasons could be the emergence of new highly-resistant non-pseudomonas strains characteristic for CF such as Stenotrophomonas maltophilia, Achromobacter xylosoxidans, and Burkholderia species ${ }^{5}$. In a recently published study for respiratory bacteriology in CF patients authors found that the average annual percent change in overall prevalence and incidence significantly decreased for $P$. aeruginosa and $B$. cepacia complex; almost did not changed for $A$. xylosoxidans while in contrast significantly increased for $S$ maltophilia. ${ }^{6}$

\section{CASE REPORT}

We present a case of cystic fibrosis in a 16-yearold boy treated in the clinic in March 2015 for pulmonary exacerbation - fever up to $38^{\circ} \mathrm{C}$, calf pain, increased cough with greenish expectoration, weight loss and fatigue. The boy was well known in the clinic, diagnosed with $C F$ since infancy, with homozygous $\Delta F 508$ mutation and a chronic Pseudomonas aeruginosa infection according to the Leeds definition ${ }^{7}$, requiring 4 to 5 intravenous 
antibiotic courses per year and regular inhalation therapy with TOBI $^{\circledR}$ until July 2014, when colistin ${ }^{\circledR}$ was introduced in his treatment plan, alternating with TOBI ${ }^{\circledR}$. After hospitalization in July 2014 the patient needed oral antibiotic courses (trimethoprim/ sulfamethoxazole and ciprofloxacin) in addition to the inhalation scheme and azithromycin 3 times weekly for 3 months. In March 2015 his lung function deteriorated with a forced expiratory volume in $1 \mathrm{~s}\left(F E V_{1}\right)$ of $22.4 \%$ from predicted. Blood results including urea, glucose and electrolytes and liver biochemistry were unremarkable. Erythrocyte sedimentation rate was elevated and full blood count showed signs of infection. A chest radiograph showed emphysema, bronchiectasis and new inflammation changes consistent with his known cystic fibrosis and new exacerbation. The sputum culture grew Stenotrophomonas maltophilia (first time for this patient). Bacterial identification was done by the BBL Enteric/Nonfermenter ID System (Becton
Dickinson). Antimicrobial susceptibility testing was performed by the E-test (LIOFILCHEM) according to the Clinical and Laboratory Standards Institute (CLSI) 2014 recommendations. ${ }^{8}$ For S. maltophilia the MIC interpretative breakpoints are available only for ticarcillin-clavulanic acid, ceftazidime, minocycline, levofloxacin, trimethoprim/sulfamethoxazole, and chloramphenicol. Other agents may be approved for therapy, but according to the CLSI, their performance has not been sufficiently studied to establish disk diffusion breakpoints. ${ }^{8}$ Antibiograms in a study of $\boldsymbol{S}$. maltophilia (isolated from snakes) demonstrated that the most effective antibiotics against these isolates were TMP-SMX, levofloxacin, ofloxacin, colistin, and gentamicin. ${ }^{9}$ A combination of doxycycline and aerosolized colistin was successfully used to treat persistent $\boldsymbol{S}$. maltophilia ventilator-associated pneumonia when high-dose TMP-SMX therapy was ineffective. ${ }^{10}$ Regarding colistin, the breakpoints established

Table 1. Antimicrobial results of our patient and the percentage of resistant strains towards each antimicrobial in 4 different studies. (Ref. 16, 21, 22, 29)

\begin{tabular}{|c|c|c|c|c|c|c|c|c|c|}
\hline \multirow[b]{2}{*}{$\begin{array}{l}\text { Antimicro- } \\
\text { bial }\end{array}$} & \multicolumn{5}{|c|}{$\%$ Resistant strains } & \multirow[b]{2}{*}{$\underset{\text { (mg/liter) }}{\mathrm{MIC}_{50}}$} & \multirow[b]{2}{*}{$\begin{array}{c}\mathrm{MIC}_{90} \\
\text { (mg/ } \\
\text { liter) }\end{array}$} & \multicolumn{2}{|c|}{ Range (mg/liter) } \\
\hline & $\begin{array}{c}\text { Our } \\
\text { patient }\end{array}$ & $\begin{array}{l}\text { P. Gon- } \\
\text { calves- } \\
\text { Vidigal } \\
(2011)\end{array}$ & $\begin{array}{c}\text { P.S } \\
\text { Gabriel } \\
(\mathbf{2 0 0 4})\end{array}$ & $\begin{array}{c}\text { H } \\
\text { Nazik } \\
(\mathbf{2 0 0 7})\end{array}$ & $\begin{array}{c}\text { K. } \\
\text { E. N. } \\
\text { Milne } \\
\text { (2012) }\end{array}$ & & & Low & High \\
\hline MIN & $\mathrm{R}$ & NA & NA & NA & 3.8 & 2 & 4 & 0.25 & 16 \\
\hline SXT & $\mathrm{R}$ & 0 & 84 & 0 & 12.7 & 0.5 & $>32$ & 0.012 & $>32$ \\
\hline $\mathrm{DOX}^{*}$ & $\mathrm{R}$ & NA & 11 & NA & 13.7 & 4 & 16 & 0.5 & 16 \\
\hline CHL & $\mathrm{R}$ & NA & NA & NA & 24.4 & 16 & 64 & 2 & $>256$ \\
\hline LVX & S & 7.7 & NA & NA & 37.5 & 4 & $>32$ & 0.25 & $>32$ \\
\hline $\mathrm{COL}^{*}$ & $\mathrm{R}$ & 30.8 & 19 & NA & 55 & 8 & $>256$ & 0.125 & $>256$ \\
\hline GEN* & $\mathrm{R}$ & NA & 65 & 64 & 84 & $>256$ & $>256$ & 1 & $>256$ \\
\hline TIM & $\mathrm{R}$ & 19.5 & 50 & NA & 64.1 & 256 & $>256$ & 1 & $>256$ \\
\hline AMK & $\mathrm{R}$ & NA & NA & 55 & 86.5 & $>256$ & $>256$ & 8 & $>256$ \\
\hline CIP* & $\mathrm{R}$ & 3 & 85 & 17 & 73.7 & 16 & $>32$ & 0.5 & $>32$ \\
\hline CAZ & $\mathrm{R}$ & 29.4 & NA & 45 & 89.6 & $>256$ & $>256$ & 2 & $>256$ \\
\hline TOB & $\mathrm{R}$ & NA & 74 & 73 & 91.2 & 256 & $>256$ & 2 & $>$ \\
\hline $\mathrm{TZP}$ & $\mathrm{R}$ & NA & 92 & 45 & 91.2 & $>256$ & $>256$ & 16 & $\begin{array}{l}104 \\
>256\end{array}$ \\
\hline PIP & $\mathrm{R}$ & NA & NA & NA & 100 & $>256$ & $>256$ & 256 & $>256$ \\
\hline IPM & $\mathrm{R}$ & NA & 97 & 100 & 100 & $>32$ & $>32$ & $>32$ & $>32$ \\
\hline MEM & $\mathrm{R}$ & NA & 92 & 100 & 100 & $>32$ & $>32$ & 32 & $>32$ \\
\hline
\end{tabular}

NA- no data in the article

MIN, minocycline; SXT, co-trimoxazole; DOX, doxycycline; CHL, chloramphenicol; LVX, levofloxacin; COL, colistin; GEN, gentamicin; TIM, ticarcillin/clavulanate; AMK, amikacin; CIP, ciprofloxacin; CAZ, ceftazidime; TOB, tobramycin; TZP, piperacillin-tazobactam; PIP, piperacillin; IPM, imipenem; MEM, meropenem.

CLSI-approved interpretive standards for $\boldsymbol{S}$ maltophilia.

* CLSI-approved interpretive standards for $\boldsymbol{P}$. aeruginosa 
for $\boldsymbol{P}$. aeruginosa were applied. ${ }^{8}$ The strain was resistant to ceftazidime, ticarcillin/clavulanic acid, minocycline, trimethoprim/sulfamethoxazole and colistin, and susceptible only to levofloxacin. In Table 1 we compare the data for our patient with the resistance level of other studies. We adjusted the therapy with levofloxacin, discontinued colistin and left only TOBI ${ }^{\circledR}$ (due to history for chronic $\boldsymbol{P}$. aeruginosa infection) for inhalation.

\section{DISCUSSION}

Chronic infection is the main determinant of morbidity and mortality in individuals with cystic fibrosis (CF). ${ }^{4}$ The bacteria most commonly believed to be pathogenic in CF include $P$. aeruginosa, $S$. aureus, $H$. influenzae, $S$. maltophilia, A. xylosoxidans, and $B$. cepacia complex. It is suggested that $S$. maltophilia is a low pathogenic species as it has limited growth in sputum from chronically infected CF patients ${ }^{11}$ which may be due to low $\mathrm{O}_{2}$ availability in the endobronchial mucus in $\mathrm{CF}$ patients ${ }^{12}$ caused by the intense $\mathrm{O}_{2}$ consumption by activated $\mathrm{PMNs}^{13}$.

In the $1960 \mathrm{~s}$ and $1970 \mathrm{~s}, P$. aeruginosa was initially not realized as a pathogen for CF patients and there were still reports until 1990 questioning its significance, while nowadays a huge part of the therapy in $\mathrm{CF}$ is targeted in eradicating and preventing this bacterium. The similarities in biofilm formation of $S$. maltophilia poses same concerns for its significance in CF. ${ }^{5}$ Since 2010 its presence has been also part of the monitored variables in $\mathrm{CF}$ patients for the registry. Data from several CF centres worldwide indicate that the prevalence of $S$. maltophilia has increased in recent years. ${ }^{14}$ Many retrospective studies show conflicting data about whether S. maltophilia is associated with lung function decline, but in one of the recent papers by Pompillo, its role in lung pathology is discussed. ${ }^{15}$ Chronic S. maltophilia infection is an independent risk factor for pulmonary exacerbation. ${ }^{16,17}$

S. maltophilia exhibits intrinsic resistance to broad-spectrum antibiotics, including beta-lactams and aminoglycosides; and thus the treatment options are limited. ${ }^{18,19}$ Recommended antibiotics for therapy against $S$. maltophilia infections in patients with CF are minocycline, doxycycline, trimethoprim/ sulfamethoxazole, colistin, and ticarcillin/clavulanic acid. ${ }^{16}$ Regarding antimicrobial susceptibility, only a few studies have performed susceptibility testing for S. maltophilia on samples from CF patients. ${ }^{20}$ Goncalves-Vidigal et al. in a recent study demon- strated that tigecycline (not available in Bulgaria) and trimethoprim/sulfamethoxazole exhibit $100 \%$ activity against $S$. maltophilia, while colistin, ceftazidime, and ticarcillin/clavulanic acid exhibited low activity against this pathogen. ${ }^{16}$ Their results are not consistent with the higher resistance rates for trimethoprim/sulfamethoxazole in USA CF patients ${ }^{21}$ but are in concordance with a Turkish study from 2007 confirming trimethoprim/sulfamethoxazole as the most active antibiotic (all isolates were susceptible) and levofloxacin getting the second place with susceptible $82 \%$ of isolates ${ }^{22}$.

These studies claim that colistin demonstrates limited activity against $S$. maltophilia isolates from CF patients. However, CLSI guidelines have not yet established specific breakpoints as interpretive criteria for colistin (administered through inhalation and not parenterally) against S. maltophilia. ${ }^{8}$

The case is interesting for us due to microorganism susceptibility only to levofloxacin, an antibiotic used very often even for minor infections, and resistant to all other available antibiotics on the market (including trimethoprim/sulfamethoxazole and colistin). In Bulgaria, to the best of our knowledge so far, all tested S. maltophilia strains were $100 \%$ susceptible to colistin [unpublished data]. This fact could be due to the very high cost of the antibiotic that should be paid by the National Health Insurance fund since April 2016 23 , and up until now the patients have had to pay for it themselves, and not all of them could afford it. Also, colistin was re-introduced to our market just last year and we are using it as antibiotic of last resort in all multidrug-resistant gram-negative infections in CF patients. ${ }^{24}$

Another point of concern for our patient is also the high prevalence of self-treatment with antibiotics in Bulgaria, found as acceptable from $73 \%$ of the studied representative part of Bulgarian population. ${ }^{25}$ Research conducted in southern Europe indicate that between $75 \%$ and $94 \%$ of the total use of antibiotics occurs in outpatient care. ${ }^{26}$ At present in Bulgaria antibiotics such as levofloxacin (our only option for the patient) and trimethoprim/sulfamethoxazole counted as "cheap and not so potent" antibiotics are widely accepted and prescribed even when not needed. ${ }^{27}$ Additionally, although in 2009 in Bulgaria a strict antibiotic policy was introduced for obligatory prescription for antibiotics, recent journalistic investigation showed that buying antibiotics without prescription 
in pharmacies is still easily done. ${ }^{28}$

To the best of our knowledge, this is the first CF patient with isolated $S$. maltophila resistant to colistin in Bulgaria. We will continue to monitor the patient closely in future to re-evaluate the therapy according the isolated microorganism susceptibility.

\section{REFERENCES}

1. Ratjen F, Döring G. Cystic Fibrosis. Lancet 2003; 361:681-9.

2. Ciofu O, Hansen CR, Høiby N. Respiratory bacterial infections in cystic fibrosis. Curr Opin Pulm Med 2013;19(3):251-258.

3. O'Sullivan BP, Freedman SD. Cystic fibrosis. Lancet 2009;373:1891-1904.

4. Döring G, Flume P, Heijerman H, Elborn JS, for the Consensus Study Group. Treatment of lung infection in patients with cystic fibrosis: current and future strategies. J Cyst Fibros 2012;11:461-479.

5. Høiby N, Pressler T. Emerging pathogens in cystic fibrosis. Eur Respir Mon 2006;35:66-78.

6. Salsgiver EL, Fink AK, Knapp EA, LiPuma JJ, Olivier KN, Marshall BC, Saiman L. Changing Epidemiology of the Respiratory Bacteriology of Patients With Cystic Fibrosis. Chest 2016;149(2):390-400.

7. Lee TWR, Brownlee KG, Conway SP, Denton M, Littlewood JM. Evaluation of a new definition for chronic Pseudomonas aeruginosa infection in cystic fibrosis patients. J Cystic Fibros 2003;2:29-34.

8. CLSI. Performance Standards for Antimicrobial Susceptibility Testing. Twenty-Third Informational Supplement. CLSI document M100-S24. Wayne, PA: Clinical and Laboratory Standards Institute, 2014.

9. Ross RA, Marzec G. 1984. The bacterial diseases of reptiles. Their epidemiology, control, diagnosis and treatment, $p 3,7-10,14-18$. Institute for Herpetological Research, Stanford University School of Medicine, Stanford, CA.

10. Wood GC, Underwood EL, Croce MA, Swanson JM, Fabian TC. Treatment of recurrent Stenotrophomonas maltophilia ventilatorassociated pneumonia with doxycycline and aerosolized colistin. Ann Pharmacother 2010;44:1665-1668

11. Kolpen M, Kragh KN, Bjarnsholt T, Line L, Hansen CR, Dalbøge CS, et al. Denitrification by cystic fibrosis pathogens - Stenotrophomonas maltophilia is dormant in sputum. Int $\mathbf{J}$ Med Microbiol 2015;305(1):1-10.

12. Worlitzsch D, Tarran R, Ulrich M, Schwab U, Cekici A, Meyer KC, et al. Effects of reduced mucus oxygen concentration in airway Pseudomonas infections of cystic fibrosis patients . J Clin Invest 2002;109(3):317-25.
13.Kolpen M, Hansen CR, Bjarnsholt T, Moser C, Christensen LD, van Gennip M, et al. Polymorphonuclear leucocytes consume oxygen in sputum from chronic Pseudomonas aeruginosa pneumonia in cystic fibrosis. Thorax 2010;65(1):57-62.

14.Zolin A, McKone EF, van Rens J, et al. ECFSPR Annual Report 2013, 2016

15.Pompilio A, Crocetta V, De Nicola S, Verginelli F, Fiscarelli E, Di Bonaventura G. Cooperative pathogenicity in cystic fibrosis: Stenotrophomonas maltophilia modulates Pseudomonas aeruginosa virulence in mixed biofilm. Front Microbiol 2015;6:951.

16. Goncalves-Vidigal P, Grosse-Onnebrink J, Mellies U, Buer J, Rath P-M, Steinmann J. Stenotrophomonas maltophilia in cystic fibrosis: improved detection by the use of selective agar and evaluation of antimicrobial resistance. J Cyst Fibros 2011;10:422-427.

17. Waters V, Yau Y, Prasad S, Lu A, Atenafu E, Crandall I, et al. Stenotrophomonas maltophilia in Cystic Fibrosis, Am J Resp Crit Care Med 2011;183,5: 635-640.

18. Nenova M. Clinical Aspects of Stenotrophomonas maltophilia associated Infections. Nauka parasititol 2011;2:28-32.

19. Stoeva T, Bojkova K, Shivachev P, Varbanova B, Jeleva M, Marinov L. Shunt Associated Infections Due to Stenotrophomonas Maltophilia in a Child with Internal Hydrocephalus. Pediatria 2007; 1:33-37.

20. Brooke J. Stenotrophomonas maltophilia: an emerging global opportunistic pathogen. Clin Microbiol Rev 2012;25(1):2-41.

21. San Gabriel P, Zhou J, Tabibi S, Chen Y, Trauzzi M, Saiman L. Antimicrobial susceptibility and synergy studies of Stenotrophomonas maltophilia isolates from patients with cystic fibrosis. Antimicrob Agents Chemother 2004;48:168-171.

22. Nazik H, Öngen B, Erturan Z, Salcioğlu M. Genotype and antibiotic susceptibility patterns of Pseudomonas aeruginosa and Stenotrophomonas maltophilia isolated from cystic fibrosis patients. Jpn J Infect Dis 2007;60:82-86.

23. List of the reimbursed medications by NHIF updated from April 2016, http://www.hapche.bg/sites/ default/files/na/izmenenie-pls-nzok.pdf

24.Grigorov E. Pharmacoeconomic assessment of the drug colistin alvogen 1000000 (IU) powder for injection/infusion solution. Social medicine 2014;1;38-41.

25. Dimitrova D, Dimova R, Levterova B. Self-treatment with antibiotics and its determinants. EGPRN Meeting "Children in General Practice" 6th -9th May, 2010, Plovdiv on "Children in General Practice" Bulgaria, European Journal of General Practice, 16, 154-173, 169-170, 2010. 
26. Grigoryan L, Burgerhof JG, Degener JE, et al. Determinants of self-medication with antibiotics in Europe: the impact of beliefs, country wealth and the healthcare system. J Antimicrob Chemother 2008;61(5):1172-9.

27.http://www.investor.bg/ikonomika-i-politika/332/a/ penkov-masovoto-izpisvane-na-antibiotici-ne-esvyrzano-s-lobistki-interesi-209285/ 28.http://news.bnt.bg/bg/a/aptekari-masovo-prodavatantibiotitsi-bez-retsepti

29. Milne KEN, Gould IM. Combination Antimicrobial Susceptibility Testing of Multidrug-Resistant Stenotrophomonas maltophilia from Cystic Fibrosis Patients. Antimicrob Agents Chemother 2012;56(8):4071-77.

\title{
Обострение заболевания легких в результате резистентной к коли- стину Стенотрофомонас мальтофилии (Stenotrophomonas maltophilia) у пациента из Болгарии с кистозным фиброзом
}

\author{
Гергана П. Стоянова ${ }^{1}$, Таня В. Стратева ${ }^{2}$, Светлана Т. Атанасова², \\ Димитринка С. Митева ${ }^{1}$, Вера Е. Папочиева ${ }^{1}$, Пенка И. Переновска ${ }^{1}$ \\ ${ }^{1}$ Клиника педиатрии, Университетская больница "Александровска" \\ 2 Кафедра медицинской микробиологии, Медицинский факультет, Софийский медицинский университет, Болгария.
}

\author{
Для корреспонденции: \\ Гергана П. Стоянова, \\ Клиника педиатрии, УМБАЛ \\ "Александровска", бул. Г. \\ Софийского № 1, 1431 София, \\ Болгария, \\ E-mail:gal_ps@yahoo.co.uk \\ Тел.: +359 889751165
}

Дата получения: 18 августа 2015 г.

Дата приемки:18 мая 2016 г. Дата публикации: 30 юня 2016 г.

Ключевые слова: кистозный фиброз, множественная лекарственная устойчивость, Stenotrophomonas maltophilia

Цитаты: Стоянова ГП, Стратева ТВ, Атанасова СТ, Митева ДС, Папочиева ВЕ, Переновска ПИ. Обострение заболевания легких в результате резистентной к колистину Стенотрофомонас мальтофилии (Stenotrophomonas maltophilia) у пациента из Болгарии с кистозным фиброзом.

Folia Medica 2016;58(2);136-140, doi: 10.1515/folmed-2016-0014.
У пациентов с кистозным фиброзом (CF), с повреждением легких, которое является вторичным по отношению к главной инфекции, это является основной причиной смертных случаев. Ввиду этого, лечение заболевания легких, направленное на сокращение воздействия инфекции, воспаления и последующего повреждения легких, имеет основное значение. Поскольку бактерия Псевдомонас аэругиноза (Pseudomonas aeruginosa) является основным патогеном у пациентов с CF, она и есть главная цель всех терапевтических стратегий, возможных режимов с приемом антибиотиков и многолетних рекомендаций. Более современные терапии с приемом антибиотиков, внедренные в течение последних десятилетий, способствуют улучшению прогноза при наличии кистозного фиброза, но наряду с этим появляются и новые патогены с множественной лекарственной устойчивостью.

Представляем случай кистозного фиброза у 16-летнего мальчика с обострением заболевания легких в результате резистентной к колистину бактерии Стенотрофомонас мальтофилия. Из данного случая проистекает ряд интересных вопросов относительно антибиотической политики и возможностей лечения в нашей стране пациентов с CF штаммами с множественной лекарственной устойчивостью. На данный момент лекарство "Колистин" используется в Болгарии как стратегическая последняя возможность для пациентов c CF, но имея ввиду появление новых, еще более устойчивых к лекарствам штаммов, терапевтический подход должен измениться: необходимо введение ограничений - к примеру на употребление Левофлоксацина, Триметоприма и Сульфаметоксазола, которые считаются "дешевыми и не настолько мощными" антибиотиками, подходящими для любой инфекции, с их применением в строгой зависимости от соответствующих результатов исследований посева. 